\title{
The Falange Española: A Spanish Paradox
}

\author{
James Slaven \\ Dalhousie University, Halifax, Canada,jm499690@dal.ca
}

\begin{abstract}
The Falange Española: a Spanish Paradox" discusses the Falange Española, a fascist political party in interwar Spain, and its power during various periods: before the Spanish Civil War and after the Spanish Civil War. First, the paper examines how the Falange Española remained a fringe movement during the time of the Second Republic, looking specifically at: the overcrowding of the political right, the lack of finances, the political mergers, etc. It then examines how the party rose to power following the outbreak of the Civil War in 1936 and the Decree of Unification in 1937, looking specifically at: membership statistics, military strength, Falangist legislation under the Franco regime, etc. The paper concludes that the party was simultaneously at the height of its power and yet the most distant from implementing its vision of a Falangist state.
\end{abstract}

KEYWORDS: Spain, Fascism, Falange Española, Political Party, Civil War

\section{Introduction}

On October 29, 1933, José Antonio Primo de Rivera founded a fascist political party in Madrid, Spain, called Falange Española (FE). This research essay will argue that the Falange remained an insignificantly small political party until the outbreak of the Civil War in 1936 and the Decree of Unification in 1937, when it was simultaneously at the height of its power and yet the most distant from implementing its vision of a Falangist state. Specifically, this essay will explore why the Falange struggled to achieve electoral success within the Second Republic, 1931-1939, and signs that it was merely just surviving within the parliamentary democratic system. Then, this essay will examine how the events following the 1936 general election led to a significant influx of new members and military power that translated into political power, ultimately allowing the party to gain important concessions and status within the Nationalist government. Finally, this essay will analyze why the Falange's power may have been more nominal than it appeared and how the Civil War distanced the party from its Falangist vision.

\section{Pre-War Period}

The FE was a distinctly fascist movement, containing "nearly all the general qualities and characteristics... of generic fascism" (Payne 1995, 261). It also exhibited several unique features: "a nostalgic view of Spain's history... anti-separatism, imperialism, and Catholicism," while promoting its national syndicalist economic agenda (Ellwood 1987, 13). For the next three years it would remain a fringe movement within Spain, reaching a peak membership of less than 10,000 members nation-wide (Payne 2004, 334). As Stanley G. Payne writes in A History of Fascism, 1914-1945: "all the way down to the beginning of the Civil War, the Falange was distinguished primarily by its insignificance" (Payne 2004, 334).

The Falange's lack of success can be primarily attributed to the fact that during the Second Republic the right-wing of Spanish politics was simply overcrowded. As Michael Mann writes in Fascists, the underlying problem for the Falangist revolutionary ideology was that "since no sudden crisis had engulfed the state, reactionary authoritarianism remained entrenched... cramping the space for populist fascism" (Mann 2004, 334). Not only was the Falange "the fifth party of the radical Right to be formed in Spain," but it was competing against multiple political parties that appealed to a mass audience, to which the Falange did not (Payne 1961, 41). These 
parties included monarchist parties such as the Renovación Españole and the Comunión Tradicionalista, and the largest of the right-wing parties, the Confederación Española de Derechas Autónomas (CEDA) (Ellwood 1987, 16, 23). CEDA's social Catholic agenda was its main draw since Catholic traditionalism maintained a large following in Spain, coupled with "the limited secularization of the rural and provincial society in much of Spain," and enabled the party to garner "mass support for conservative interests," ultimately drawing away potential supporters of Falangism (Blinkhorn 2003, 120; Payne 1995, 263; Riley 2010, 98, 110; Payne 1987, 104).

As a result, the Falange experienced financial difficulty early on. The party had been launched just a few weeks before the 1933 general elections, which ended up bringing a centreright coalition into power (Mann 2004, 308). As Sheelagh M. Ellwood writes in Spanish Fascism in the Franco Era: "the electoral victory of the 'moderate' Right had temporarily quelled the anxieties of the conservative upper and middle classes and the attraction of radical ideologies consequently diminished" (Ellwood 1987, 14). As a result, the party's financial support had also dried up. The party's finances were in such a bad state that by the end of the year it was forced to consider merging with the Juntas de Ofensiva Nacional Sindicalista (JONS) - a party that had occupied essentially the same ideological space as the Falange, and thus whose "possibilities of growth and recruitment" were undermined by the sheer existence of the Falange (Ellwood 1987, 14-5, 17; Riley 2010, 101). The two groups eventually ended up merging on February 13, 1934 and collectively became known as the Falange Española de las JONS.

However, the party had not yet navigated out of the dire financial straits it had found itself in. By summer of that same year, the Falange made another deal with a political party. This time, it was the Renovación Española, who received a number of guarantees from the Falange (ex. José Antonio pledged not to oppose the party's aspirations to restore the monarchy) and in return subsidized the FE. As Ellwood notes: "at the expense of its independence and ideological purity... [José Antonio] had, in effect, sold out to the patron offering greatest possibilities of survival" (Payne 1995, 263; Ellwood 1987, 16-7). The Falange lacked the level of widespread support needed to even just financially sustain itself, much less to transform Spain into the national syndicalist state it dreamed of.

The electoral results of 1936, wherein the Falange received less than $1 \%$ of the vote, clearly illustrated the inability of the Falange to effectively penetrate mainstream right-wing Spanish politics, and contend "for the same political clientele" as the pre-existing right-wing parties (Ellwood 1987, 13). The fact that the Falange sought electoral success and representation within the parliamentary democracy was inherently contradictory - the Falange sought to overthrow the Second Republic, not to become a part of it (Ellwood 1987, 23). However, even though it seemed, according to the results of the election, as if the Falange had been decisively defeated, the general election of 1936 was really a victory for the Falange.

\section{Wartime \& Post-War Periods}

This research essay has, thus far, explored how the Falange Española remained a fringe political movement prior to 1936. It will now argue that the party rose to the height of its power following the 1936 general election, the Civil War, and the Decree of Unification in 1937.

The election of 1936 and the subsequent Civil War marked the turning of the political tides for the Falange. The results of the election meant that, as Dylan Riley explains in The Civic Foundations of Fascism in Europe, "the right could not achieve power in Spain through electoral means," and conspired to gain power through more "radical methods" (Riley 2010, 103; Payne 
1961, 94). Spanish conservative forces had failed to hold back 'the invasion of the barbarians,' as José Antonio referred to the elected, 'communist' Popular Front, and now the only tools available to save Spain were those that the Falange had been preaching and (partially) practicing all along (Ellwood 1987, 13, 29-30, 32). Thus, in the post-election atmosphere, much more serious consideration was given to the dynamism and revolutionary aspect of Falangism - in the months leading up to the Civil War, party membership doubled to somewhere between 20,000 and 25,000 members (Payne 1961, 83, 98; Mann 2004, 334). By contrast, the power of the mainstream conservative parties, notably CEDA, was on the downturn. As Payne writes in Falange, "discredited by their past failures and present impotence, the old political groups virtually ceased to function" (Payne 1961, 121). By the summer of 1936, CEDA, previously the largest right-wing political party in Spain, "was beginning to dissolve" (Riley 2010, 98-9; Grugel and Rees 1997, 8, 14). By the time of the Decree of Unification in April, 1937, CEDA ceased to exist, Renovación Española was insignificant, and so the Unification essentially just merged two groups: the Falange (now the largest political party in the Nationalist zone) and the Comunión Tradicionalista (Grugel and Rees 1997, 14; Payne 1987, 106).

When the Civil War began on July 18, 1936, the power of the Falange could be measured in terms of its new, military power. During the first days of the war, at a time when the Nationalist forces only numbered, at most, 40,000 on the Iberian peninsula, it was able to contribute several thousand troops to the Nationalist war effort throughout almost all of Spain (Ellwood 1987, 32; Payne 1961, 117, 120). In the opening weeks, the Falangist militias "often occupied large sections of the still poorly defined front," proving crucial during the early stages of the war, while "at all times [assuring] the flanks and the rearguard," as one army officer, Rafael Casas de la Vega, wrote (Payne 1961, 120; Ellwood 1987, 32). By April, 1937, the Falange was contributing 126,000 troops according to conservative estimates, and made up over half of the Nationalist militia forces (Payne 1961, 146; Ellwood 1987, 33). This was a significant feat considering that, just a year ago, only 44,000 votes were cast nation-wide for the FE. In fact, the Falange was recruiting at such a high rate that "membership soon passed all manageable proportions" (Payne 1961, 121). For example, a recruiting station in Zaragoza enlisted 2,000 militiamen within twenty-four hours of first opening (Ellwood 1987, 33).

The number of troops that the Falange contributed to the Nationalist war effort was so substantial and indispensable that they were able to acquire a number of concessions in exchange from the Caudillo, Francisco Franco. One of the first indicators of the amount of military power the Falange possessed, and therefore also the amount of political power it could exert within the structure of the Franco regime, is the number of ministerial and administrative positions to which Falangists were appointed. For example, in August, 1939, almost half of Franco's cabinet was made up of Falangists, with the next largest representation of any one group being the military who held just two cabinet positions (Bowen 2006, 65). Between 1936 and 1945, some estimates indicate that Falangists were appointed to the highest percentage of positions (31.6 percent), followed by "representatives of the armed forces" (25.1 percent), and so on (Bowen 2006, 64). As Payne notes in Fascism in Spain, 1923-1977, other estimates suggest that military personnel occupied the highest percentage of positions, while Falangists occupied the second highest: "military personnel would hold 45.9 percent of the ministerial appointments and 36.8 percent of the top government positions... Falangists, by comparison, would hold 37.9 percent of the ministerial appointments and only 30.3 percent of all top administrative positions" (Payne 1999, 312). Either way, the fact remains that Falangists held a significant number of ministerial and 
administrative positions which supports the statement that it represented one of the most significant military and political forces in the new state.

Another, and perhaps one of, if not the most, significant indicator of the Falange's power within the Franco regime was the Fuero de Trabajo, the regime's labour charter, instituted on March 9, 1938. This was meant to be the piece of legislation with which the Falange would begin to transform Spain into a fascist state with a national syndicalist, 'third way,' economy-a distinctly Falangist state (Ellwood 1987, 19). As Ellwood writes:

[The] Decree encapsulates... the contribution of the Falange at a critical moment in the formation of the regime... Indeed, the very notion of a State whose economic and social organization was to be based on State-run, lay, non-class based, obligatory unions of workers and employers was essentially Falangist. (Ellwood 1987, 62-3)

It, crucially, created the basic framework on which the national syndicalist economy was to be built, which was a hallmark of Falangism, as Ellwood mentioned. Shortly thereafter, the Central Obrera Nacional Sindicalista (Workers' National Syndicalist Union) and the Central de Empresarios Nacional Sindicalista (Employers' National Syndicalist Union) were merged into one Central Nacional Sindicalista (National Syndicalist Centre; CNS). The CNS essentially aimed to organized the economy and its workers into "a huge union of producers... ordered as militias" who would "be subordinated to the national interest," and whose hierarchy would be entirely composed of Falangists (Grugel and Rees 1997, 61, 63). The establishment of the CNS was a distinctly Falangist creation, too, in terms of both its ideological roots and who would command it. The Feuro de Trabajo, along with the CNS, gave the regime one of its most Falangist characteristics - the beginnings of a national syndicalist state-demonstrating the power and influence that the Falange possessed within the Franco regime.

A third indicator of the Falange's power within the new state was the degree to which Falangist ideology, symbols, and rituals were incorporated into the government and with which the regime actively identified. The Franco regime adopted Falangist symbols as its own, including: the Twenty-Six Points of the Falange (slightly adapted from the original TwentySeven Points) as the official "statutes of the new party," along with "the straight-armed fascist salute, the use of 'comrade' as a term of address, the red and black banner... the anthem 'Face to the Sun,' the blue shirt uniform of the Falangists, and the "Falangist yoke and arrows" (a classic imperialist symbol of the Catholic Kings of 15th-century Spain) (Payne 1998, 108; Grugel and Rees (Payne 1998, 108; Grugel and Rees 1997, 15; Ellwood 1987, 45; Payne 1961, 18). Not only were these symbols officially adopted by the state, they were actively identified with. For example, anyone who held an official government "post had to swear fidelity to the ' 26 points of Falange" " (Ellwood 1987, 59). Even José Antonio became something of a cultish icon in the new state. As Payne writes: "José Antonio Primo de Rivera had become the official symbol and patron saint of the new dictatorship" (Payne 1961, 190). November 16, beginning in 1938, was declared "an annual day of national mourning," in the memory of the death of José Antonio (Ellwood 1987, 65). He was idealized to such a point that at the end of the war, José Antonio's remains were led by "a torchlight procession of Falange militiamen... over a three-hundred-mile trek," ending at the El Escorial, "the resting place of Spain's kings," where he was reinterred (Payne 1961, 190-1). 
The regime also actively identified with Falangist symbols and ideology as a result of the Falange's monopoly over state propaganda. The Falange had been given complete control over the production of official propaganda when a Falangist (or at very least a Falangist sympathizer), Serrano Suñer, was appointed to the position of Press and Propaganda Chief and Minister of the Interior, in early 1938 (Payne 1961, 181; Ellwood 1987, 68). This even translated into a successful bid on the behalf of the FE to play a greater role in the educational sphere. As Ellwood writes, "although education was primarily the prerogative of the Church," teachers had to pass through Falangist colleges, Falangist literature was read, and even Falangist music had to be sung (Ellwood 1987, 58). Through controlling the state propaganda machine as well as having a hand in educating Spain's youth, the party was able to gradually indoctrinate the population. As Martin Blinkhorn writes in Fascists and Conservatives: "[Falangism] was the source of the regime's lexicon, iconography, and ideological paraphernalia" (Blinkhorn 2003, 138). Thus, the party's power can be examined through the expression of Falangist ideology, symbols, and rituals within the new state.

The final indicator of the Falange's power was the Decree of Unification. Issued on April 20, 1937, it united the FE and Comunión Tradicionalista while also outlawing and dissolving all other political parties (Ellwood 1987, 42, 44). What emerged from the Unification became known as the Falange Española Tradicionalista y de las JONS (FET) (Ellwood 1987, 42). The FET would "be set up and administered by Falangists" rather than what was left of the remaining right-wing parties (Payne 1961, 175). The Falange was now the partido unico-the singular party of the new state (Payne 1987, 107). Meanwhile, the party would create and manage its own departments, "taking in every aspect of government activity," and shared power with the government bureaucracy already in existence (Payne 1961, 176). As Ellwood points out: "[the Unification] was... ideologically justified [by the Falangists], for it represented the 'final thrust for the conquest of the State,' envisaged by the last of the Falange's original 27 Programmatic Points" (Ellwood 1987, 45). At first glance, it appears that the Falange was the closest it had ever been to creating a Falangist state: they were now the only state in existence, there was no political opposition (in theory), and "Franco and his staff [were] still occupied... primarily with military affairs," according to Payne (Payne 1961, 174). The metaphorical, political gate had been left seemingly wide open.

While the outbreak of the Civil War and the Decree of Unification did indeed mark the period of the height of the Falange's power, this research essay will now argue that they simultaneously distanced the Falange from its vision.

Although the Decree of Unification established the Falange as the official state party, and the only one that was legally allowed to exist, it would also permanently affix Franco as jefe nacional - the national leader of the party. As Blinkhorn writes:

The role of the FET... within Franco's Spain was designed from the outset to be instrumental and subordinate to leader and state... It had lost any autonomous dynamism when, after the unification, it allowed itself to provide the bureaucratic structure of the new Francoist state. (Blinkhorn 2003, 134, 140)

The Falange had believed that the Unification would benefit the Nationalist war effort by consolidating its political forces and attempting to reduce any internal struggle for power (Payne 1961, 175). That belief, combined with few available options besides accepting the Decree, had also been backed up by the Cuartel General, the nationalist military command, who agreed that following the war, the Falangist programme would be implemented (Payne 1961, 175). So, while 
the Decree of Unification outlawed Falange's political opposition, making it the only party to officially exist, it had also permanently subjugated the the party to the state.

Another indicator of the gap between Francoist Spain and a Falangist Spain was the membership of the Falange. As this research essay has already discussed, following the 1936 general election, and particularly after the outbreak of the Civil War, the membership of the Falange increased dramatically. Throughout the war and thereafter, its membership would continue to increase, reaching almost one million members by 1941 (Payne 1999, 370). However, as is to be expected with such a large political movement, not all of its members were hardcore Falangists-Falangist veterans became known as camisas viejas (Payne 1961, 175). From the beginning of the Civil War, the Falange's core was diluted by former members of CEDA, and particularly by the 15,000 former members of its youth organization (Mann 2004, 335-6). The FE struggled to sufficiently indoctrinate its new members, as Payne writes: "There was a distinct threat that the party might become an amorphous, directionless mass... The new members had but the scantiest indoctrination; most of them knew only that the Falange stood for something 'new' and 'social' " (Payne 1961, 122). In fact, as the National zone expanded during the course of the war and the more of the Spanish populace came under their control, former Leftists "joined the Falange as a means of saving themselves" (Payne 1961, 122). Even former Communists, who the Falangists regularly vilified, were absorbed into the party folds (Payne 1961, 122). This of course meant that the ideological purity of the Falange was compromisedpercentagewise, fewer members aspired to implement the Falangist vision. As Payne writes in "Franco, the Spanish Falange and the Institutionalisation of Mission": "[the Falange] in Europe 'survived' by becoming the least fascist of all its major counterparts" (Payne 2006, 199).

It is also important to recognize that not all of the members of the Falange (particularly after Unification) were active members, and remained members in title only, as Payne points out: "the bulk of the... male membership was relatively passive and only rarely mobilized... FET administration was content with a nominally large but little mobilized and basically passive membership" (Payne 1987, 238-9). Even had the party's new members been true believers of Falangism, without the ability to mobilize them, the Falange never could have implemented its vision.

A third, more theoretical, indicator of the distance of the Falange from the achievement of its vision, is that the Civil War divided the nation instead of unifying it. While in a Republican jail in Alicante (having been arrested on July 14, 1936) José Antonio rightly realized that the FE's participation in the Civil War was inadvertently undermining its vision and thwarting its long term plans for a fascist state, which by definition is nationally unified (Payne 1961, 132-3). As Payne explains José Antonio’s concern:

[José Antonio] was appalled to think that the force of the Falange might be expended in a long and enervating struggle between Right and Left in which the nation as a whole would come out the loser. The aftermath of such a conflict would be the exact negation of that spirit of national unity he had preached. If the Left won, it would destroy all hope for restoring Spain to its historical Catholic solidarity. If the Right won, there would be black reaction, maintained only by force and smothering the vital energies of the nation. (Payne 1961, 133)

Although the Falange had long advocated for the use of violence in order to overthrow the Second Republic, the Civil War in theory was a problem - in order to gain power, the Falange needed to battle the state, but by battling the state, the Falange would create division within the nation. José Antonio's concerns were manifested most violently in the White Terror, during 
which the Nationalists maintained order and security through brutal police repression and the murder of thousands of civilians (Payne 1961, 183). What the former jefe would have found most disturbing was that Falangists actively participated in these repressive actions: "Party Secretary Raimundo Fernández Cuesta admitted... that the Falangists 'did the dirty work, like carrying out executions" "(Ellwood 1987, 33). Not only did the White Terror deepen the divisions between Leftists and Rightists, Republicans and Nationalists, but it was the Falange that was doing it, distancing itself from the realization of its dream of a "spirit of national unity" (Payne 1961, 133). So while the outbreak of the Civil War facilitated an increase of the Falange's ranks thereby amplifying its military and political power, it also undermined the Falangist vision: the longer the war went on, the more the Falange grew, but the more distant its vision of a fascist, nationally unified state became. At this rate, a Falangist state would never be realized.

A similarly theoretical indicator, and the final indicator to be examined by this research essay, is based in the relationship between the Falange and the Nationalist Army, and the power dynamic between the two. Once again, José Antonio had rightly been concerned about who exactly was leading the rebellion against the Republicans - the Falange needed to be strong enough to exert its own will and demonstrate its own initiative during the war, otherwise it risked become subservient to other forces (Ellwood 1987, 40). He "had warned against the risks inherent to subscribing to the 'political plans of the military men,' " and had even been reluctant to join in the insurrection at first (Ellwood 1987, 70; Payne 1961, 110). However, as Payne notes:

[The Falange] was in no position to dispute supremacy with the Army, if the Army really planned to rebel. Once the military conspiracy became a concrete fact, the Falange could only go along with it or be crushed by a militant Right or a victorious Left. (Payne 1961, 110)

Although José Antonio had tried to negotiate the terms of the insurrection with the military, in order to gain some sort of authority within the Nationalist cause, the Falange was kept largely out of the planning and remained relatively, politically isolated (Payne 1961, 110-1). Thus, when the plan was hatched, the Falange would not be its leader, and was forced to instead support the leadership of the Nationalist Army. Then, in the absence of Primo's leadership, the party had allowed itself, and its Falangist militias, to be gradually absorbed into the Nationalist government and the formal structure of the Nationalist Army, respectively (Ellwood 1987, 39-40). As Payne writes:

The Falange had to rely on the initiative and leadership of military forces to carry out the insurrection which would provide its only chance of survival. Even before the death of José Antonio, the movement had been forced to surrender its full autonomy. Independence once lost would never be regained. (Payne 2006, 193)

The Falange had surrendered its autonomy, willing or not, and therefore its power, when the military had initiated and proceeded to lead the Civil War. Ultimately this trend prevailed - in 1943 "the formal defascistization of the FET began," and by 1945 the radical Falangists had been purged from the party - some 6,000 members - effectively silencing those that remained within it, and signifying the "domestication of the party" (Payne 1999, 370). Franco had tamed the party, stripping it of its autonomy and initiative, and therefore had distanced the party from its vision (Payne 1998, 112). 


\section{Conclusion}

This essay first argued that the Falange Española was an insignificant political party prior to 1936, largely due to the overcrowding of the right-wing of Spanish politics, as indicated by the deals it was forced to make with other parties just to survive. Secondly, this essay argued that its membership, and therefore its military and political power, rose significantly following the 1936 general election, the outbreak of the Civil War, and the Decree of Unification in 1937. This was examined through the actual numbers of troops the Falange contributed itself, the ministerial and administrative appointments Falangists received within the Nationalist government, the establishment of the Fuero de Trabajo and the beginnings of a national syndicalist state, the degree to which Falangist ideology, symbols, and rituals were adopted and actively identified with within the new state, and finally the status that the Unification granted to the party. Thirdly, this essay argued that while the Falange was at the height of its power following the Civil War and the Decree of Unification, it was simultaneously the furthest away from the creation of a Falangist state. This was supported by the examination of the Unification as a double-edged sword that had subjugated the party to Franco, the ideological deficiency and passiveness of the Falange's new membership, how the divisions created by the Civil War inevitably made a nationally unified, fascist state less and less likely, and how the party had surrendered its autonomy, and therefore the initiative required to implement Falangism, to the Nationalist Army. In summary, while the power of the Falange Española increased dramatically, compared to its pre-1936 status, the party had simultaneously and ultimately distanced itself from the realization of its Falangist vision

\section{References}

Blinkhorn, Martin. 2003. Fascists and Conservatives: The Radical Right and the Establishment in Twentieth-century Europe. London: Routledge.

Bowen, Wayne H. 2006. Spain during World War II. Columbia: University of Missouri Press.

Ellwood, Sheelagh M. 1987. Spanish Fascism in the Franco Era: Falange Española De Las Jons, 1936-76. New York: St. Martin's Press.

Grugel, Jean, and Rees, Tim. 1997. Franco's Spain. Contemporary History Series. London, New York: Arnold: Distributed Exclusively in the USA by St. Martin's Press,

Mann, Michael. 2004. Fascists. Cambridge, New York: Cambridge University Press.

Payne, Stanley G. 1961. Falange: A History of Spanish Fascism. Stanford Studies in History, Economics, and Political Science, 22. Stanford, Calif.: Stanford University Press.

Payne, Stanley G. 1987. "Spanish Fascism." Salmagundi, no. 76-77: 101-12.

Payne, Stanley G. 1998. "Fascist Italy and Spain, 1922-45." Mediterranean Historical Review 13(1-2): 99-115.

Payne, Stanley G. 1999. Fascism in Spain, 1923-1977. Madison: University of Wisconsin Press.

Payne, Stanley G. 2004. A History of Fascism, 1914-1945. Madison: University of Wisconsin Press.

Payne, Stanley G. 2006. "Franco, the Spanish Falange and the Institutionalisation of Mission." Totalitarian Movements and Political Religions 7(2): 191-201.

Payne, Stanley G. 1987. The Franco Regime, 1936-1975. Madison, Wis.: University of Wisconsin Press.

Riley, Dylan J. 2010. The Civic Foundations of Fascism in Europe: Italy, Spain, and Romania, $1870-1945$. Baltimore: Johns Hopkins University Press. 